\title{
PARENTAL INVOLVEMENT IN LEARNING ENVIRONMENT, SOCIAL INTERACTION, COMMUNICATION, AND SUPPORT TOWARDS CHILDREN EXCELLENCE AT SCHOOL
}

\author{
Ahmad, N.A, Hassan, S.A., Ahmad, A.R., Chua, L.N., and Othman, N.
}

\begin{abstract}
Parental role and involvement are important to produce excellent children in spiritual and physical aspects. Malaysia Education Blueprint (2013-2025) through SARANA program has been implemented at schools in Malaysia to increase involvement and participation of parents in giving support towards children excellence. The aim of this study is to identify the level of parental involvement and support in learning. Parents Self-Assessment (PSA) has been distributed randomly to 391 parents during Parents meeting at schools. The analysis of parental involvement focused on four main domains which are providing learning environment at home, social interaction with children, communication with children, and support towards children excellence. The findings shows that providing learning environment at home (mean $=0.78, \mathrm{~s} . \mathrm{d}=0.23$ ), social interaction with children (mean=5.40, s.d=1.63), and communication with children (mean=4.68, s.d=1.89) are at higher level mean score, while support towards children excellence show average mean score (mean=3.90, s.d=1.94). The implication of the study is that support towards children excellence in praises, encouragement and guidance need to be improved by parents to help the school to increase achievement in education.
\end{abstract}

\section{KEYWORD:}

parental involvement; learning environment; social interaction; communication; support towards children excellence.

\section{INTRODUCTION}

Parents play important role in creating an environment that is able to support or weaken adolescent experience to become competent in learning and socializing in school (Skinner dan Wellborn, 1994). Experience from parental involvement will help the adolescent development in terms of cognitive and emotion, develop confidence and positive behavior, and able to succeed in the study and other activities that they join either in or outside of school. Epstein et al. (2002) listed six domains of parental involvement which are parenting, communicating, volunteering, learning at home, decision-making, and cooperating with the community. These domains have been emphasized to ensure the effectiveness of the relationship between parents, school and community.

There are some factors that cause parents less involved in supporting child learning especially at school. Parental involvement at school is rather disappointing because they lack the understanding of the definition of parental involvement, do not know how to help children academically, lack of encouragement from teachers, parents only contact school when in need, and the treatment of teachers towards parents (Young et al., 2013). Wa Wong and Hughes (2006) stated the parental involvement depends on nation, ethnicity, and culture in which mostly parents from minority, low wages and low education are reluctant to involve with school. Feelings not welcome and not fluent in the language also contribute to parents' reluctance in involving in school activities (Turney \& Kao, 2009). These factors lead to parental confusion in understanding teacher and school desire, parents' lack of motivation to involve in school activities and lastly, parents fail to support the needs of children's learning.

In terms of learning at home, parents become less involved when the child starts to enter high school because they thought that they did not have the skills to help their child to learn or to do assignments (Eccles \& Harold, 1993; Deplanty et al., 2007). The parents worry that what they have learned at school before no longer similar to what their child has learned nowadays, so they choose not to help so that their child won't get confused with what the teachers have taught them at school. While some parents thought that 
their child already reaches the certain age which makes them able to independent and solve the school assignments and learn without the needs of guidance, help or being monitored (Drummond \& Stipek, 2004). When the parents no longer involve in learning at home, their children can easily lose focus and less motivated in learning.

To increase parental involvement in supporting child learning, the school has to play the main roles to create school culture which not only accepting the parental involvement but also appreciates them (Ferguson, 2005). The teachers have to deliver clear information and effective two-way communication must be applied to help parents to understand school desire, teacher needs and the importance of parental involvement in helping child learning either at school or at home. Child and adolescents at lower and higher school need support and attention from parents especially to help them succeed in next phase of life. The more confidence developed in parents towards child success in school, the more involvement of parents in child learning (Eliason \& Jenkins, 2003).

\section{Problem Statement}

SARANA is a tool which used to achieve or to do something. In Malaysia Education Blueprint (2013-2025), SARANA program has been implemented since the year 2013 with aims to increase parental involvement in child learning in and outside of school for education excel. The school is the main drive in increasing parental involvement and community with the help of Parent Support Group (PSG). Each year, a school that meets criteria listed by Malaysia Ministry of Education will be crowned as School Excel SARANA and it is a pride for every school to achieve that. However, there is no depth research has been done on the effectiveness of this program in educating parents the importance of their involvement in child learning in and outside of school. Past researchers found that parental involvement helps in increasing student academic achievement and positive behaviors (Jeynes, 2007; Toldston, 2008; Plunkett et al., 2008; Kordi \&Baharudin, 2010), student less aggressive and decreasing in dropout rates (Kratochwill et al, 2004), student become competent (Hill et al.,
2004) and student more motivated (Khan et al., 2014).

A gap of academic achievement between boys and girls in public exam in Malaysia become widen and give implication on the imbalance of male and females students proportion at local university (Ahmad et al., 2011). Imbalance academic achievement between genders is not an issue that occurs in Malaysia, but has been further studied and discussed in other countries. Gap achievement between genders is significant and has been widening in five years (Mohd Jelas et al., 2013). Achievement of female students always higher than male students at all stages. Gap achievement between genders begins to be seen from the public exam at primary school until university which is $70 \%$ of university cohort is female students. Although this is not a unique phenomenon in Malaysia, still it needs attention to make sure the country does not have a cohort of dropout male students either they are leaving school system early or those in lower achievement group. To fulfill the restructuring of existing education systems to better quality education system, a survey on roles, readiness and the needs of parental involvement must be done so that the education of each child is guaranteed.

\section{Research Aim}

The aim of the study is to identify the level of parental involvement in four main domains which are learning environment, social interaction, communication and support towards children excellence.

\section{Problem Statement}

I. How far the level of parental involvement in learning environment?

II. How far the level of parental involvement in social interaction?

III. How far the level of parental involvement in communication?

IV. How far the level of parental involvement in support towards children excellence?

\section{ReSEARCh ObJective}

Population and sample

Research population consists of parents from chosen primary and secondary school in Negeri Sembilan. These schools have an excellent record 
in parental involvement based on report and criteria listed by Malaysia Ministry of Education. There are six criteria in determining school excel in SARANA which are school climate, effective communication, support towards student excellence, responsibility, decision-making and collaboration with the community.

\section{Data collection}

400 set questionnaire of Parental SelfAssessment (PSA) has been distributed in three primary and secondary schools which show higher involvement of parental involvement in Negeri Sembilan. But, only 391 set questionnaire has been returned to the researcher.

\section{Research instrument}

Parental Self-Assessment (PSA) questionnaire has been adapted from Malaysia Ministry of Education 2015. The questionnaire is used to enable parents to do self-assessment on their involvement in child learning and take actions on what needed.

The questionnaire consists two parts which are:

A. Demography (5 item)

B. Parent/Guardian involvement in child learning at home (20 item)

i. Learning environment at home (5 item)

ii. Social interaction with child (5 item)

iii. Communication with child (5 item)

iv. Support towards child excellence (5 item)

Table 1

Distribution of items according to domain in Parental Self Assessment (PSA)

\begin{tabular}{|l|l|l|}
\hline Domain & No. Item & Bil. Item \\
\hline $\begin{array}{l}\text { Learning environment at } \\
\text { home }\end{array}$ & $1,2,3,4,5$ & 5 \\
\hline $\begin{array}{l}\text { Social interaction with } \\
\text { child }\end{array}$ & $1,2,3,4,5$ & 5 \\
\hline $\begin{array}{l}\text { Communication with } \\
\text { child }\end{array}$ & $1,2,3,4,5$ & 5 \\
\hline $\begin{array}{l}\text { Support towards child } \\
\text { excellence }\end{array}$ & $1,2,3,4,5$ & 5 \\
\hline
\end{tabular}

\section{Data analysis}

The data has been analyzed by using descriptive and inferential statistics through Statistical Package for the Social Science (SPSS) version 19 to answer research questions.

\section{FINDINGS}

The level of parental involvement analysis focused on four main aspects which are: i) learning environment at home, ii) social interaction with child, iii) communication with child and iv) support towards child excellence.

Table 2

Interpretation of mean score for domain learning environment at home

\begin{tabular}{|c|c|}
\hline Mean Score & Tendency Level \\
\hline $0.00-0.33$ & Low \\
\hline $0.34-0.66$ & Moderate \\
\hline $0.67-1.00$ & High \\
\hline
\end{tabular}

Table 2 shows the interpretation of mean score for domain learning environment at home divided by three tendency level of parental involvement which is high (mean score $=0.67-1.00$ ), moderate (mean score $=0.34-0.66)$ and low (mean score $=0.00-0.33)$.

Table 3

Mean of Parental Self Assessment (PSA) for domain learning environment at home

\begin{tabular}{|l|l|l|l|l|l|}
\hline Domain & $\begin{array}{l}\text { No. of } \\
\text { Re- } \\
\text { spon- } \\
\text { dent }\end{array}$ & $\begin{array}{l}\text { Mini- } \\
\text { mum } \\
\text { value }\end{array}$ & $\begin{array}{l}\text { Maxi- } \\
\text { mum } \\
\text { Value }\end{array}$ & $\begin{array}{l}\text { Mean } \\
\text { Score }\end{array}$ & $\begin{array}{l}\text { Stan- } \\
\text { dard } \\
\text { Devia- } \\
\text { tion }\end{array}$ \\
\hline $\begin{array}{l}\text { Learning } \\
\text { environ- } \\
\text { ment at } \\
\text { home }\end{array}$ & 391 & 0.00 & 1.00 & 0.78 & 0.23 \\
\hline
\end{tabular}

Table 3 shows the mean score for the domain learning environment at home is high which 0.78 .

Table 4

Interpretation of mean score for domain social interaction with child, communication with child and support towards child excellence

\begin{tabular}{|c|c|}
\hline Mean Score & Tendency Level \\
\hline $0.00-2.33$ & Low \\
\hline $2.34-4.66$ & Moderate \\
\hline $4.67-7.0$ & High \\
\hline
\end{tabular}

Table 4 shows the interpretation of mean score for domain social interaction with child, 
communication with child and support towards child excellence divided by three tendency level of parental involvement which are high (mean score $=4.67-7.00$ ), moderate (mean score $=2.34-4.66)$ and low (mean score $=0.00-2.33)$.

Table 5

Mean of Parental Self Assessment (PSA)

for domain social interaction with child, communication with child and support towards child excellence

\begin{tabular}{|l|l|l|l|l|l|}
\hline Domain & $\begin{array}{l}\text { No. of } \\
\text { Respon- } \\
\text { dent }\end{array}$ & $\begin{array}{l}\text { Mini- } \\
\text { mum } \\
\text { value }\end{array}$ & $\begin{array}{l}\text { Maxi- } \\
\text { mum } \\
\text { Value }\end{array}$ & $\begin{array}{l}\text { Mean } \\
\text { Score }\end{array}$ & $\begin{array}{l}\text { Stan- } \\
\text { dard } \\
\text { Devia- } \\
\text { tion }\end{array}$ \\
\hline $\begin{array}{l}\text { Social inter- } \\
\text { action with } \\
\text { child }\end{array}$ & 391 & 0.00 & 7.00 & 5.40 & 1.63 \\
\hline $\begin{array}{l}\text { Communica- } \\
\text { tion with } \\
\text { child }\end{array}$ & 391 & 0.00 & 7.00 & 4.68 & 1.89 \\
\hline $\begin{array}{l}\text { Support } \\
\text { towards child } \\
\text { excellenc }\end{array}$ & 391 & 0.00 & 7.00 & 3.90 & 1.94 \\
\hline
\end{tabular}

Table 5 shows the interpretation of mean score for social interaction with child, communication with child and support towards child excellence. Analysis of mean score for domain social interaction with child is high which 5.40 .

Domain for communication with child also show high mean score which is 4.68 .

Meanwhile, analysis for domain support towards child excellence show moderate mean score which is 3.90 .

Overall, three domain of parental involvement which are learning environment at home, social interaction with child and communication with child is higher compared to the domain of support towards child excellence which is at moderate level.

Table 6

Mean score for items in domain learning environment at home

\begin{tabular}{|l|l|l|l|l|l|}
\hline Item & $\begin{array}{l}\text { No. of } \\
\text { Respon- } \\
\text { dent }\end{array}$ & $\begin{array}{l}\text { Mini- } \\
\text { mum } \\
\text { value }\end{array}$ & $\begin{array}{l}\text { Maxi- } \\
\text { mum } \\
\text { Value }\end{array}$ & $\begin{array}{l}\text { Mean } \\
\text { Score }\end{array}$ & $\begin{array}{l}\text { Standard } \\
\text { Devia- } \\
\text { tion }\end{array}$ \\
\hline $\begin{array}{l}\text { I provide } \\
\text { space for } \\
\text { child to learn } \\
\text { at home }\end{array}$ & 391 & 0 & 1 & .91 & .289 \\
\hline $\begin{array}{l}\text { I ensure my } \\
\text { child has } \\
\text { learning } \\
\text { schedule at } \\
\text { home }\end{array}$ & 391 & 0 & 1 & .52 & .500 \\
\hline
\end{tabular}

\begin{tabular}{|l|l|l|l|l|l|}
\hline $\begin{array}{l}\text { I reduce the } \\
\text { noise of } \\
\text { radio/televi- } \\
\text { sion when } \\
\text { my child is } \\
\text { learning }\end{array}$ & 391 & 0 & 1 & .77 & .423 \\
\hline $\begin{array}{l}\text { I ensure that } \\
\text { my child's } \\
\text { learning } \\
\text { space is } \\
\text { always neat } \\
\text { and clean }\end{array}$ & 391 & 0 & 1 & .89 & .316 \\
\hline $\begin{array}{l}\text { My child have } \\
\text { sufficient } \\
\text { reference } \\
\text { books }\end{array}$ & 391 & 0 & 1 & .83 & .375 \\
\hline
\end{tabular}

Table 6 shows the mean score for five items in domain learning environment at home. Four items show high mean score which is "I provide space for child to learn at home" (mean score=0.91), "I ensure that my child's learning space is always neat and clean" (mean score $=0.89)$, "My child have sufficient reference books" (mean score $=0.83$ ) and "I reduce the noise of radio/television when my child is learning" (mean score $=0.77$ ). Meanwhile, item "I ensure my child has a learning schedule at home" shows moderate score mean which is 0.52. Analysis for this domain shows that parents alert on basic needs for child to learn by providing comfortable space for learning and providing additional reading material, but they less involve in ensuring the child has suitable and flexible learning timetable to help them more focus on learning activities at home.

Table 7

Mean score for items in domain social interaction with child

\begin{tabular}{|l|l|l|l|l|l|}
\hline Item & $\begin{array}{l}\text { No. of } \\
\text { Respon- } \\
\text { dent }\end{array}$ & $\begin{array}{l}\text { Mini- } \\
\text { mum } \\
\text { value }\end{array}$ & $\begin{array}{l}\text { Maxi- } \\
\text { mum } \\
\text { Value }\end{array}$ & $\begin{array}{l}\text { Mean } \\
\text { Score }\end{array}$ & $\begin{array}{l}\text { Standard } \\
\text { Devia- } \\
\text { tion }\end{array}$ \\
\hline $\begin{array}{l}\text { I chat with } \\
\text { my child }\end{array}$ & 391 & 0 & 1 & 5.86 & 1.991 \\
\hline $\begin{array}{l}\text { I eat with my } \\
\text { child }\end{array}$ & 391 & 0 & 1 & 5.68 & 2.091 \\
\hline $\begin{array}{l}\text { I spares time } \\
\text { to do activi- } \\
\text { ties with my } \\
\text { child }\end{array}$ & 391 & 0 & 1 & 4.25 & 2.506 \\
\hline $\begin{array}{l}\text { I take noted } \\
\text { on my child } \\
\text { movement }\end{array}$ & 391 & 0 & 1 & 5.95 & 1.989 \\
\hline $\begin{array}{l}\text { I give reli- } \\
\text { gion/moral- } \\
\text { education to } \\
\text { my child }\end{array}$ & 391 & 0 & 1 & 5.25 & 2.371 \\
\hline
\end{tabular}


Table 7 shows the mean score for five items in domain social interaction with the child. Four items show high mean score which is "I take noted on my child movement" (mean score=5.95), "I chat with my child" (mean score $=5.86$ ), item "I eat with my child" (mean score=5.68) and item "I give religion/moral education to my child" (mean score $=5.25$ ). Meanwhile, item "I spare time to do activities with my child" shows moderate mean score which is 4.25. Analysis of this domain shows parents are concern in monitoring activities and movements of children, try to interact and converse with child during the family hour and strict in fulfilling the needs of religion and moral education. However, parents still lack in participating or doing activities with child at home such as cooking, playing fun activities or jogging together.

Table 8

Mean score for items in domain communication with child

\begin{tabular}{|l|l|l|l|l|l|}
\hline Item & $\begin{array}{l}\text { No. of } \\
\text { Respon- } \\
\text { dent }\end{array}$ & $\begin{array}{l}\text { Mini- } \\
\text { mum } \\
\text { value }\end{array}$ & $\begin{array}{l}\text { Maxi- } \\
\text { mum } \\
\text { Value }\end{array}$ & $\begin{array}{l}\text { Mean } \\
\text { Score }\end{array}$ & $\begin{array}{l}\text { Standard } \\
\text { Devia- } \\
\text { tion }\end{array}$ \\
\hline $\begin{array}{l}\text { My child and } \\
\text { I discuss his/ } \\
\text { her progress } \\
\text { in study }\end{array}$ & 391 & 0 & 1 & 4.54 & 2.343 \\
\hline $\begin{array}{l}\text { I listen to my } \\
\text { child's story } \\
\text { about events } \\
\text { at school }\end{array}$ & 391 & 0 & 1 & 4.80 & 2.205 \\
\hline $\begin{array}{l}\text { I concern } \\
\text { about my } \\
\text { child's home- } \\
\text { work }\end{array}$ & 391 & 0 & 1 & 4.71 & 2.421 \\
\hline $\begin{array}{l}\text { I concern } \\
\text { about my } \\
\text { child's plan- } \\
\text { ning activities }\end{array}$ & 391 & 0 & 1 & 4.76 & 2.433 \\
\hline $\begin{array}{l}\text { I can } \\
\text { exchange } \\
\text { opinions with } \\
\text { my child }\end{array}$ & 391 & 0 & 1 & 4.58 & 2.396 \\
\hline
\end{tabular}

Table 8 shows the mean score for five items in domain communication with child. Three items show high mean score which is "I listen to my child's story about events at school" (mean score $=4.80$ ), "I concern about my child's planning activities" (mean score $=4.76$ ) and "I concern about my child's homework" (mean score=4.71). Two items show moderate mean score which is "I can exchange opinions with my child" (mean score $=4.58$ ) and "My child and I discuss his/her progress in study" (mean score $=4.54)$. Analysis of this domain shows that there is basic communication between parents and child at home, but only a few parents who deeply discuss school or talk about another issue outside the school with their children.

Table 9

Mean score for items in domain support towards child excellence

\begin{tabular}{|l|l|l|l|l|l|}
\hline Item & $\begin{array}{l}\text { No. of } \\
\text { Respon- } \\
\text { dent }\end{array}$ & $\begin{array}{l}\text { Mini- } \\
\text { mum } \\
\text { value }\end{array}$ & $\begin{array}{l}\text { Maxi- } \\
\text { mum } \\
\text { Value }\end{array}$ & $\begin{array}{l}\text { Mean } \\
\text { Score }\end{array}$ & $\begin{array}{l}\text { Standard } \\
\text { Devia- } \\
\text { tion }\end{array}$ \\
\hline $\begin{array}{l}\text { I praise and } \\
\text { give stimulus } \\
\text { to child }\end{array}$ & 391 & 0 & 1 & 4.43 & 2.426 \\
\hline $\begin{array}{l}\text { I give encour- } \\
\text { agement or } \\
\text { motivation to } \\
\text { child }\end{array}$ & 391 & 0 & 1 & 4.65 & 2.505 \\
\hline $\begin{array}{l}\text { My fam- } \\
\text { ily and I } \\
\text { do reading } \\
\text { activity }\end{array}$ & 391 & 0 & 1 & 3.33 & 2.469 \\
\hline $\begin{array}{l}\text { I guide my } \\
\text { child to } \\
\text { complete } \\
\text { homework }\end{array}$ & 391 & 0 & 1 & 3.70 & 2.655 \\
\hline $\begin{array}{l}\text { I provide } \\
\text { guidance or } \\
\text { tuition to } \\
\text { child }\end{array}$ & 391 & 0 & 1 & 3.41 & 2.575 \\
\hline
\end{tabular}

Table 9 shows the mean score for five items in domain support towards child excellence. All five items show moderate mean score which is "I give encouragement or motivation to child" (mean score $=4.65)$, "I praise and give stimulus to child" (mean score $=4.43$ ), "I guide my child to complete homework" (mean score $=3.70$ ), "I provide guidance or tuition to child" (mean score $=3.41$ ) and "My family and I do reading activity" (mean score $=3.33$ ). Analysis of this domain shows that parents positively give praises, encouragement and motivation to their children, but only a few of them spend times to give guidance and do academic activities together with children.

\section{Discussion AND SUggestion}

Findings of the study show that majority of parents realize and take action in providing a suitable learning environment for children such as providing study space and reference books. In communication and social interaction domain, parents tend to have a conversation, ask child's activities and discuss their problems. But, parental involvement only achieve moderate level when 
it involves academic activities with child such as reading, helping and guiding child to complete homework.

Cooper (1989) stated that parental actions in controlling physical and social environment of children such as checking and helping children finish their homework, give rewards when child get good grades, give amercement for bad grades, and limit time for television, play or socialize with friends can contributes to support in academic excel. Parental involvement also affects school orientation by helping in decreasing dropout problems and truancy among students (Shumow \& Miller, 2001). When the parents involve by monitoring school tasks and homework, giving encouragement for child to participate in school activities, having a good relationship with the teacher and helping child by discussing their future together, students tend to show better performance at school (Khajehpour, 2011).

Past researches also found that academic achievement and student social development affect by parental involvement in child learning (Epstein, 2001) such as discussion about school (Jeynes, 2005; Lee \& Bowen, 2006; Stewart, 2008), positive communication between parents and students (Celenk, 2003), comfortable house environment (Begum, 2007), and parents help child to complete homework and do discussions with teacher at school (Lavenda, 2011). Parental involvement not only gives encouragement to child to participate in school activities and improve their achievement in learning (You \& Sharkey, 2009), but affect their interest, motivation and attitude at school (Shumow et al., 2011).

Thus, researcher suggests that after Parents Self-Assessment (PSA) questionnaire has been distributed by a school to the parents, the school should recollect them again to avoid lose of information, data can be analyzed and the results can be shared with parents. After the parents acknowledge their involvement level towards child learning at home, they can refer their problems at school counselor, teacher or parents support group (PSG) for further guidance and advice to increase their level of involvement in supporting child learning. School also can do intervention program to help parents to involve more and at the same time it can help in increasing student academic achievement.

\section{REFERENCE}

Ahmad, N. A., Mohd Jelas, Z. \& Mohd Ali, M. (2011). The Relationship of Learning Styles and Learning Strategies with Academic Achievement between Gender and Type of School. International Journal on Learning. 17(10): 265-278.

Begum, N. N. (2007). Effect of parent involvement on math and reading achievement of young children: Evidence from the early childhood longitudinal study. Unpublished doctoral dissertation, Indiana University of Pennsylvania, Pennysylvania.

Celenk, S. (2003). Okul basarisinin onkosulu: Okul aile danismasi [The prerequisite for school success: home-school cooperation]. Ilkogretim-Online. 2(2): 28-34.

Cooper, H. (1989). Homework. New York: Longman.

DePlanty, J., Coulter-Kern, R. \& Duchane, K. A. (2007). Perceptions of parent involvement in academic achievement. The Journal of Educational Research. 100(6). 361-368.

Drummond, K. V. \& Stipek, D. (2004). Low income parents' beliefs about their role in children's academic learning. Elementary School Journal. 104: 197-213.

Eccles, J. S. \& Harold, R. D. (1993). Parent-school involvement during the early adolescents years. Teachers College Record. 94: 568587.

Eliason, C. \& Jenkins, L. (2003). A practical guide to early childhood curriculum. 7 th ed. New Jersey: Prentice Hall.

Epstein, J. (2001). School, family, and community partnerships: Preparing educators and improving schools. Boulder, CO: Westview Press.

Epstein, J. L., Sanders, M. G., Simon, B. S., Salinas, K. C., Jansorn, N. R., \& Van Voorhis, F. L. (2002). School, family, and community 
partnerships: Your handbook for action (2nd ed.). Thousand Oaks, CA: Corwin.

Ferguson, C. (2005). National Center for Family \& Community connections with schools. Southwest Educational Development Laboratory. 1-7.

Hill, N. E., Castellino, D. R., Landsford, J. E., Nowlin, N., Dodge, K. A., \& Bates, J. E. (2004). Parent academic involvement as related to school behaviour, achievement and aspirations: Demographic variations across adolescence. Child Development. 75(5): 1491-1509.

Jeynes, W. H. (2005). Effects of parental involvement and family structure on the academic achievement of adolescents. Marriage and Family Revive. 37(3): 99-116.

Jeynes, W. H. (2007). The relationship between parental involvement and urban secondary school student academic achievement: A meta-analysis. Urban Education. 42(1): 82 110 .

Khajehpour, M. (2011). Relation between emotional intelligence, parental involvement and academic performance of high school students. Procedia Social and Behavioral Sciences. 15: 1081-1086.

Khan, A., Ahmad, R., Hamdan, A. R. \& Mustaffa, M. S. (2014). Educational encouragement, parenting styles, gender and ethnicity as predictors of academic achievement among special education students. International Education Studies. 7 (2): 18-24.

Kordi, A., \& Baharudin, R. (2010). Parenting attitude and style and its effect on children's school achievements. International Journal of Psychological Studies. 2: 217-222.

Kratochwill, T. R., McDonald, L., Levin, J. R., Bear-Tibbets, H. Y., \& Demaray, M. K. (2004). Families and school together: An experimental analysis of parent-mediated multi-family group program for American Indian children. Journal of School Psychology. 42: 359-383.

Lavenda, O. (2011). Parental involvement in school: A test of Hoover- Dempsey and Sandler's model among Jewish and Arab parents in Israel. Children and Youth Services Review. 33: 927-935.

Lee, Jung-Sook \& Bowen, N. K. (2006). Parent involvement, cultural capital, and the achievement gap among elementary school children. American Educational Research Journal Summer. 43(2): 193-218.

Mohd Jelas, Z., Mohd. Salleh, A., Azman, N., Hamzah, R., Jani, R. Hamzah, H., Abd Hamid, Z. \& Mahmud, M. I. (2013). Analisis Gender Dalam Pendidikan: Laporan Akhir Kajian KPT.R.620-1/1/3. 32(17).

Plunkett, S. W., Henry, C. S., Houltberg, B. J., Sands, T., \& Abarca-Mortensen, S. (2008). Academic support by significant others and educational resilience in Mexican origin ninth grade students from intact families. Journal of Early Adolescence, 28, 333-355.

Shumow, L., \& Miller, J. (2001). Father's and mother's school involvement during early adolescence. The Journal of Early Adolescence. 21: 69-92.

Shumow, L., Lyutykh, E. \& Schmidt, J. A. (2011). Predictors and Outcomes of Parental Involvement with High School Students in Science. The School Community Journal. 21(2): 81-98.

Skinner, E. A., \& Wellborn, J. G. (1994). Coping during childhood and adolescence: A motivational perspective. In D. Featherman, R. Lerner \& M. Perlmutter (Eds.) Life span development and behaviour. pp. 91-133. Hillsdale, NJ: Erlbaum.

Stewart, E. B. (2008). School structural characteristics, student effort, peer associations, and parental involvement. Education and Urban Society. 40(2); 179 204.

Tolston, I. A. (2008). Breaking barriers: Plotting the path to academic success for school-age African American males. Washington DC: Congressional Black Caucus Foundation, Inc.

Turney, K. \& Kao, G. (2009). Barriers to school environment: Are immigrant parents 
Ahmad, N.A, Hassan, S.A., Ahmad, A.R., Chua, L.N., and Othman, N.

disadvantaged? Journal of Educational Research. 102(4): 257-271.

Wa Wong, S. \& Hughes, J. N. (2006). Ethnicity and language contributions to dimensions of parent involvement. School Psychology Review. 35(4): 645-662.
You, S., \& Sharkey,J. (2009). Testing a developmentecological model of student engagement: A Multilevel latent growth curve analysis. Educational Psychology. 29: 659-684.

Young, C. Y., Austin, S. M. \& Growe, R. (2013). Defining parental involvement: Perception 